\title{
New and noteworthy records of the moss flora of Korea
}

\author{
Wonhee KIM*, Masanobu HIGUCHI ${ }^{1}$, Tomio YAMAGUCHI ${ }^{2}$, \\ Takumi SATO ${ }^{3}$ and Yuya INOUE ${ }^{2}$ \\ National Institute of Biological Resources, Incheon 22689, Korea \\ ${ }^{I}$ Department of Botany, National Museum of Nature and Science, Tsukuba 305-0005, Japan \\ ${ }^{2}$ Program of Basci Biology, Graduate School of Integrated Science for Life, Hiroshima University, Higashi-hiroshima 739-8526, Japan \\ ${ }^{3}$ Hattori Botanical Laboratory (Citizen researcher), Nichinan 889-2535, Japan \\ (Received 11 August 2020; Revised 24 September 2020; Accepted 10 December 2020)
}

\begin{abstract}
A total of 34 taxa, 33 species and one variety, are newly added to the moss checklist of Korea. They were collected on Jejudo Island, Samcheok limestone areas in Gangwon Province, and Socheongdo Island from 2015 to 2018 and organized into 19 families and 26 genera. Additionally, eight genera are new to Korea. This study verifies the distributions of nine species whose distributions and specimens have remained unknown thus far. Finally, two unrecorded taxa, consisting of one species and one variety, are identified by reexamining Korean specimens deposited at the National Museum and Science in Japan (TNS). The specimens were collected in 1942 and 1940 from Mt. Baekdusan and Anbyun in North Korea.
\end{abstract}

Keywords: unrecorded, moss, Korea, limestone, Socheongdo Island, Jejudo Island

This study deals with the new records for the moss flora of Korea based on recent collections conducted by the authors and the specimens deposited at the herbarium of the National Museum of Nature and Science in Japan. We conducted field studies in Jejudo Island, Socheongdo Island, and Gangwon-do from 2015 to 2018. Jejudo Island is known as the region with the highest biodiversity on the Korean Peninsula. Socheongdo Island has a small area of $2.91 \mathrm{~km}^{2}$, but it is the only area in South Korea where the stromatolites of the Precambrian Eon are found. The limestone areas of Gangwon-do are known to have a variety of rare plants adapted to alkaline soil. In addition, about 360 Korean specimens deposited at the herbarium of the National Museum of Nature and Science in Japan (TNS) were examined. They were collected from 1914 to 1943, and their localities include Geumgangsan Mt., Baekdusan Mt., and Chailbong in North Korea. Unfortunately, there are no specimens left in South Korea, which had been collected at the beginning of the 20th century. Therefore, the specimens deposited at TNS are valuable materials to study Korean Bryofloa. Park and Choi (2007) compiled a checklist of Korean bryophytes, and list 291 genera and 645 species of mosses from Korea. We added 34 moss species new to the flora of Korean bryophytes.

\section{Materials and Methods}

Field studies were carried out from 2015 to 2018, and a total of ca. 1,593 bryophyte specimens were collected. About 360 moss specimens of Korea are kept at TNS. The specimens newly obtained through this study are kept in the National Institute of Biological Resources (KB), and some duplicates are also kept in the herbaria of the TNS and the Hiroshima University (HIRO) in Japan.

\section{Results and Discussion}

\section{New records}

A total of 34 mosses are new to Korea based on the collections made by the authors mainly in Jejudo Island. Newly added mosses are organized as 19 families and 26 genera. Eight genera of them are also new to Korea, which are Platydictya, Ardeuma, Chenia, Eucladium, Geheebia,

\footnotetext{
*Author for correspondence: whkimoss@gmail.com
} 
Syntrichia, Heterocladium, and Campylostelium. Among about 360 moss specimens of Korea deposited at the herbarium of the TNS, Grimmia longirostris and Brachythecium buchananii var. gracillimum are confirmed as new records based on the specimens collected from Baekdusan Mt. in 1942 and Anbyun, Gangwon-do, North Korea, in 1940, respectively.

\section{Reconfirmed records}

Park and Choi (2007) listed new mosses from Korea, but they did not present any references and specimens. We reconfirmed 9 species of them in this study. The asterisk (*) indicates them.

\section{Enumeration}

The mosses recognized in this study are listed below. The scientific names follow Frey et al. (2006), Goffinet et al. (2009), and Ignatov et al. (2012). The families, genera and species are arranged alphabetically. Each species is referred by localities, elevation, dates, collector, specimen numbers and range of the distribution.

\section{Amblystegiaceae}

1. *Hygrohypnum purpurascens Broth.

Specimen examined: SOUTH KOREA. Gyeonggi-do: Yangju-si, Jangheung-myeon, 37² $42^{\prime} 39.1^{\prime \prime} \mathrm{N}, 126^{\circ} 59^{\prime} 41.2^{\prime \prime} \mathrm{E}$, elev. ca. 260 m, 27 Jun 2016, NIBRMS106348 (KB).

Distribution: China, Japan, and Korea.

This species was first recorded by Park and Choi (2007), and, they recognized $H$. purpurascens as a synonym of Hygrohypnum subeugyrium. However, it is based on the dissertation of Jamieson (1976), the taxonomic treatment is not validly published. Therefore, this study recognizes that the correct name is Hygrophypnum purpurascens. Furthermore, Park and Choi (2007) didn't present any references and specimens. Therefore, the present study first verifies that this species is distributed in Korea.

\section{Platydictya subtilis (Hedw.) H. A. Crum}

Specimen examined. SOUTH KOREA. Gangwon-do: Pyeongchang-gun, Jinbu-myeon, Jangjeon-ri, around the Balsimsa Temple, elev. 870 m, 2 Jun 2017, NIBRMS107472 (KB).

Distribution: China, Japan, India, Bhutan, Caucasus, Europe, North America, and Korea.

Plants of Platydictya are minute and their stems are creeping. This species is widely distributed in the Northern Hemisphere, and is known to grow on calcareous region at high elevations. Pyeongchang-gun, which is the collecting site of this species, is known as a limestone area in Korea.

\section{Bartramiaceae}

3. Philonotis hastata (Duby) Wijk \& Margad.

Specimen examined: SOUTH KOREA. Gangwon-do: Pyeongchang-gun, Jinbu-myeon, Makdong-ri, 37³3'15.4"N, $128^{\circ} 32^{\prime} 44^{\prime \prime}$, elev. $620 \mathrm{~m}, 30$ May 2017, NIBRMS107444 (KB).

Distribution: China, Japan, Indonesia, the Philippines, Madagascar, Hawaii, and Korea.

This species is an acrocarpous moss, small and slender. This species is distinguished from stem leaf shape and costa. Stem leaves are oblong-lanceolae or ovate-oblong, and costa extends near the apex of leaf.

\section{Brachytheciaceae}

\section{Brachythecium buchananii var. gracillimum Dixon}

Specimen examined: NORTH KOREA. Hamgyeongnamdo: Anbyon (Anbyeon)-gun, 1 Aug 1940, N. Ohyama 1637 (TNS).

Distribution: Japan and Korea.

This variety is firstly reported from Korea by examining specimens deposited at TNS.

\section{Brachythecium camptothecioides Takaki}

Specimen examined: SOUTH KOREA. Gangwon-do:

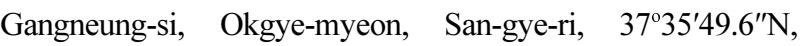
$128^{\circ} 55^{\prime} 19.6^{\prime \prime}$, elev. 230 m, 4 May 2015, NIBRMS107339 (KB).

Distribution: Japan and Korea.

This species is known as an endemic species of Japan (Noguchi, 1991; Higuchi, 2011). Usually, this species grows on calcareous rocks. Okgye-myeon is a typical limestone area in Korea.

\section{Brachythecium nitidulum (Broth.) Nog.}

Specimen examined: SOUTH KOREA. Gangwon-do: Gangneung-si, Okgye-myeon, San-gye-ri, 37³5'49.6'N, $128^{\circ} 55^{\prime} 19.6^{\prime \prime} \mathrm{E}$, elev. $230 \mathrm{~m}, 4$ May 2015, NIBRMS107349 (KB).

Distribution: Japan and Korea.

This species is minute and slender, and its stem leaf apex is shortly acuminate, and is known to an endemic species of Japan (Noguchi, 1991; Higuchi, 2011).

\section{Kindbergia arbuscula (Broth.) Ochyra}

Specimens examined: SOUTH KOREA. Jeju-do: Jeju-si, Jocheon-eup, Seonheul-ri, 33⒉ $7^{\prime} 30.9^{\prime \prime} \mathrm{N}, 26^{\circ} 43^{\prime} 23.4^{\prime \prime} \mathrm{E}$, elev. ca. 400 m, 2 Nov 2015, NIBRMS107414 (KB); Jeju do, Jeju- 
si, Jocheon-eup, Seonheul-ri, N3327'33.6", E 12643'33", elev. 360 m, 30 Jun 2016, NIBRMS107469 (KB).

Distribution: China, Japan, and Korea.

This species is dendroid plant form. There is a taxonomic controversy about a taxonomical position of this species. Noguchi (1991) and Hu et al. (2008) recognized this species as a member of Eurhynchium. Therefore, it is necessary to analyze its phylogeny by using molecular data.

\section{Rhynchostegium ovalifolium S. Okamura}

Specimen examined: SOUTH KOREA. Gangwon-do: Samcheok-si, Dogye-eup, Mugeon-ri, $37^{\circ} 15^{\prime} 25^{\prime \prime} \mathrm{N}, 129^{\circ} 6^{\prime} 53.2^{\prime \prime} \mathrm{E}$, elev. 620 m, 5 May 2015, NIBRMS107357-b (KB).

Distribution: China, Japan, and Korea.

\section{Bryaceae}

9. Osculatia coronata (Schwägr.) Ochyra, Plášek \& Bedn.Ochyra

Specimen examined: SOUTH KOREA. Jeju-do: Seogwiposi, Daejeong-eup, around the Songaksan Mt., 3312'13.4"N, $126^{\circ} 17^{\prime} 22.4^{\prime \prime} \mathrm{E}, 11$ Sep 2016, elev. 35 m, NIBRMS107396 (KB).

Distribution: China, Japan, widely distributed in the Northern Hemisphere, and Korea.

This species is distinguished by costae, which are excurrent into long awns, somewhat pellucid, and usually grows on sandy soils in an open and bright place.

\section{Dicranaceae}

10. Campylopodium medium (Duby) Giese \& J.-P. Frahm

Specimens examined: SOUTH KOREA. Jeju-do: Jeju-si, Jocheon-eup, Seonheul-ri, 332 $27^{\prime} 19.5^{\prime \prime} \mathrm{N}, 126^{\circ} 43^{\prime} 18.9^{\prime \prime} \mathrm{E}$, elev. ca. 330 m, 8 Sep 2016, NIBRMS107387, NIBRMS107388 (KB).

Distribution: China, Japan, Indonesia, Malaysia, the Philippines, Pacific Islands, Chile, Puerto Rico, and Korea.

This species is small. Noguchi (1989) commented that Japanese plants are usually distributed in the volcanic region. Jejudo Island is a volcanic island.

\section{Dicranella gonoi Cardot}

Specimen examined: SOUTH KOREA. Incheon: Ongjingun, Daecheong-myeon, $37^{\circ} 49^{\prime} 40.3^{\prime \prime} \mathrm{N}, 124^{\circ} 42^{\prime} 16^{\prime \prime} \mathrm{E}$, elev. ca. 56 m, 2 Nov 2017, NIBRMS107463 (KB).

Distribution: China, Japan, and Korea.

This species is small and erect. Leaves are up to $3 \mathrm{~mm}$ long, costa extending to the apex and smooth back.

\section{Diphysciaceae}

\section{Diphyscium mucronifolium Mitt.}

Specimens examined: SOUTH KOREA. Jeju-do: Seogwipo-si, Namwon-eup, Harye-ri Valley, around the Hyomyeongsa, $33^{\circ} 19^{\prime} 31.1^{\prime \prime} \mathrm{N}, 126^{\circ} 35^{\prime} 31.2^{\prime \prime} \mathrm{E}, 370 \mathrm{~m}$ elev., 1

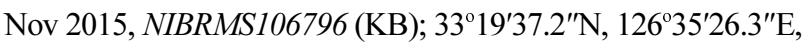
elev. 430 m, 1 Nov 2015, NIBRMS106800 (KB).

Distribution: China, Japan, India, Southeat Asia, Malaysian peninsula, the Philippines, New Guinea, Australia, North America and Korea.

Diphyscium has unique features, which are inner perichaetial leaves and capsules. In particular, a capsule on a very short seta is surrounded by long perichaetial leaves, and obliquely ovoid-conic form. This species is distinguished by stomata absent on the capsule and awn straight of inner perichaetial leaves.

\section{Ditrichaceae}

13. Ditrichum flexicaule (Schwägr.) Hampe

Specimen examined: SOUTH KOREA. Incheon: Ongjingun, Daecheong-myeon, $37^{\circ} 49^{\prime} 40.3^{\prime \prime} \mathrm{N}, 124^{\circ} 42^{\prime} 16^{\prime \prime} \mathrm{E}$, elev. ca. 56 m, 2 Nov 2017, NIBRMS107460 (KB).

Distribution: China, The Far East Russia, Europe, North America, and Korea.

This species is known to usullay grow on calcareous soils, and distinguished by a tomentose stem.

\section{Ditrichum rhynchostegium Kindb.}

Specimen examined: SOUTH KOREA. Jeju-do: Seogwiposi, Namwon-eup, Harye-ri, $33^{\circ} 17^{\prime} 8^{\prime \prime} \mathrm{N}, 126^{\circ} 36^{\prime} 32^{\prime \prime} \mathrm{E}$, elev. ca. 120 m, 31 Oct 2015, NIBRMS107428 (KB).

Distribution: Canada, USA, Japan, Taiwan, and Korea.

This study verifies the distribution of this species in Korea for the first time. According to Seppelt et al. (2007), Korea was included in the Asian distribution list of this species. However, no reference to Korean specimens and specific locality was described.

\section{Entodontaceae}

15. *Entodon morrisonensis Nog.

Specimen examined: SOUTH KOREA. Gangwon-do: Gangneung-si, Okgye-myeon, San-gye-ri, 37 35'49.6'N, $128^{\circ} 55^{\prime} 19.6^{\prime \prime}$, elev. ca. 230 m, 4 May 2015, NIBRMS107355 (KB).

Distribution: China, Taiwan, and Korea.

This species was firstly recorded by Park and Choi (2007), but references are not presented. In this study, a distribution area of this species is first verified in Korea. This species is similar to $E$. giraldii, but differs from the latter by dorsal leaves contricted at base and short median cells. 


\section{Fissidentaceae}

16. *Fissidens bryoides var. lateralis (Broth.) Z. Iwats. \& Tad. Suzuki

Specimens examined: SOUTH KOREA. Jeju-do: Jeju-si,

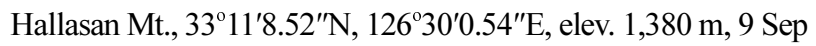
2016, NIBRMS106982 (KB); 33⒉1'13.74"N, 126 30'2.58"E, elev. 1,390 m, 9 Sep 2016, NIBRMS106988 (KB); Jeju-si,

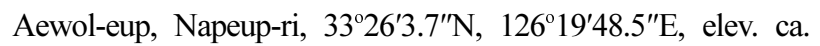
130 m, 1 Jul 2016, NIBRMS106352 (KB).

Distribution: China, Japan, and Korea.

This variety was firstly reported by Park and Choi (2007), but references are not presented. In this study, a distribution area in Korea is verified for the first time. The complex of $F$. bryoides is variable, and 3 taxa including this variety are distributed in Korea. This variety differs in female inflorescences mostly lateral and perichaetial leaves much small.

\section{Fissidens crenulatus Mitt.}

Specimen examined: SOUTH KOREA. Jeju-do: Seogwiposi, Namwon-eup, Harye-ri, $33^{\circ} 17^{\prime} 8^{\prime \prime} \mathrm{N}, 126^{\circ} 36^{\prime} 32^{\prime \prime} \mathrm{E}$, elev. ca. 120 m, 31 Oct 2015, NIBRMS107430 (KB).

Distribution: China, Japan, Nepal, India, Myanmar, Vietnam, Malaysia, Micronesia, the Philippines, New Guinea, and Korea.

This species is small and grows on soil. Characteristics of this species are leaf laminal cells with single distinct papilla, leaf margin crenate or distinctly serrulate except for that of vaginant lamina.

\section{Fissidens geminiflorus Dozy \& Molk.}

Specimens examined: SOUTH KOREA. Gangwon-do: Samcheok-si, Dogye-eup Mugeon-ri, 37³3'28.7'N, 129 6'34"E, elev. ca. 550 m, 31 May 2017, NIBRMS107445 (KB); Samcheoksi, Gagok-myeon, Punggok-ri, 37 ${ }^{\circ}{ }^{\prime 22.4} 4^{\prime \prime N}, 129^{\circ} 9^{\prime} 59.8^{\prime \prime} \mathrm{E}$, elev. ca. 400 m, 1 Jun 2017, NIBRMS107446 (KB).

Distribution: China, Japan, Indonesia, the Philippines, and Korea.

This species is large, and its stem is upto ca. $60 \mathrm{~mm}$ long. Leaf laminal cells are mamillose, absent papillae, and leaf margin is serrulate.

19. Fissidens hyalinus Wilson \& Hook.

Specimen examined: SOUTH KOREA. Jeju-do: Seogwiposi, Namwon-eup, Harye-ri, around the 2nd Harye Bridge, $33^{\circ} 17^{\prime} 8^{\prime \prime} \mathrm{N}, 126^{\circ} 36^{\prime} 32^{\prime \prime} \mathrm{E}$, elev. ca. $120 \mathrm{~m}, 31$ Oct 2015 , NIBRMS107425 (KB).

Distribution: China, Japan, India, North \& South America, and Korea.

This species is simply distinguished from other ones of Fissidens by eacostae leaves. This plant is small and slender.

\section{Grimmiaceae}

20. Grimmia longirostris Hook.

Specimen examined: Pettou Mt. (白頭山, Baekdusan Mt.), 13 Sep 1942, Y. Kobayashi s. no. (TNS 85302 as Grimmia affinis).

Distribution: China, Japan, India, Nepal, New Guinea, Canary Islands, Russia, Europe, North Africa, America, and Korea.

This species was firstly reported by Park and Choi (2007). They recognized that $G$. ovalis was a synonym of $G$. longirstris. However, their taxonomic treatment was not based on any taxonomic revision study. Therefore, this study doesn't agree to Park and Choi (2007). Still, we discovered a specimen of G. affinis collected from Baekdusan Mt. in TNS. Grimmia affinis is a synonym of $G$. longirostris. As a result, it is first verified that $G$. longistrostris is distributed in Korea.

\section{Hypnaceae}

21. Pseudotaxiphyllum densum (Cardot) Z. Iwats.

Specimen examined: SOUTH KOREA. Gangwon-do: Gangneung-si, Okgye-myeon, San-gye-ri, 37 $35^{\prime} 49.6^{\prime \prime} \mathrm{N}$, $128^{\circ} 55^{\prime} 19.6^{\prime \prime} \mathrm{E}$, elev. 230 m, 4 May 2015, NIBRMS107350 (KB).

Distribution: China, Japan, and Korea.

Pseudotaxiphyllum is distinguished from related genera, which are Isopterygium and Taxiphyllum, by lacking pseudoparaphyllia. This plant is not reddish, and smaller than P. pohliaecarpum.

\section{Leskeaceae}

22. Claopodium gracillimum (Cardot \& Thér.) Nog.

Specimen examined: SOUTH KOREA. Jeju-do: Seogwiposi, Namwon-eup, Harye-ri, near the 2nd Harye Bridge, the dry valley, $33^{\circ} 17^{\prime} 8^{\prime \prime} \mathrm{N}, \mathrm{E} 126^{\circ} 36^{\prime} 32^{\prime \prime} \mathrm{E}$, elev. $120 \mathrm{~m}, 31$ Oct 2015, NIBRMS107427 (KB).

Distribution: China, Japan, and Korea.

Claopodium consists of 8 species in the world (Wu et al., 2002), and 6 species among them are distributed in Korea including this species. The leaves of this species have smooth marginal cells and unipapillose median cells. This species is known to be usually distributed at the limestone region in Japan (Noguchi, 1991).

23. *Leskeella pusilla (Mitt.) Nog. 
Specimen examined: SOUTH KOREA. Jeju-do: Seogwiposi, Seogwi-dong, around the Lee Jung-seop Museum, $33^{\circ} 14^{\prime} 44^{\prime \prime} \mathrm{N}, 126^{\circ} 33^{\prime} 52.3^{\prime \prime} \mathrm{E}$, elev. ca. 35 m, 1 Jul 2016, NIBRMS107439 (KB).

Distribution: Japan and Korea.

Noguchi (1991) and Park and Choi (2007) reported distribution of this species in Korea. However, its specimens have been not yet known. In this study, it is verified to be distributed in Jejudo Island. This species is small and stem creeping.

\section{Meteoriaceae}

24. Neodicladiella pendula (Sull.) W. R. Buck

Specimen examined: SOUTH KOREA. Jeju-do: Jeju-si, Jocheon-eup, Seonheul-ri, Geomunorum, 3327'33.6"N, 1264'32.8"E, 2 Nov 2015, NIBRMS107482 (KB).

Distribution: China, Japan, North America, Mexico, and Korea.

Neodicladiella consists of two species, $N$. fragellifera and this species. Characteristics of Neodicladiella are that plants creeping, secondary stems slender, filiform, and pendulous, and both species are usually distributed in tropical or subtropical regions. This species is distinguished from $N$. fragellifera by multipapillose leaf cells.

\section{Pottiaceae}

25. Ardeuma aurantiacum (Mitt.) R. H. Zander \& Hedd. Specimen examined: SOUTH KOREA. Gangwon-do: Gangneung-si, Okgye-myeon, San-gye-ri, $37^{\circ} 35^{\prime} 50^{\prime \prime} \mathrm{N}$, $128^{\circ} 55^{\prime} 18^{\prime \prime}$, elev. 250 m, 4 May 2015, NIBRMS107361 (KB).

Distribution: China, Japan, Laos, the Philippines, Thailand, Central Asia, South America, and Korea.

This species is similar to A. recurvirostrum. Zander and Eckel (2017) mentioned that this species has long elliptic leaves with a strong apiculus or short mucro, and costa not percurrent. These characteristics differ from those of $A$. recurvirostrum.

\section{Chenia leptophylla (Müll. Hal.) R. H. Zander}

Specimens examined: SOUTH KOREA. Jeju-do: Seogwipo-si, Sojeongbang Waterfall, evergreen broad-leaved forest, $33^{\circ} 14^{\prime} 44.6^{\prime \prime} \mathrm{N}, 126^{\circ} 34^{\prime} 38.0^{\prime \prime} \mathrm{E}$, elev. ca. $38 \mathrm{~m}, 29$ Jun 2016, NIBRMS107478 (KB); Gangwon-do: Gangneung-si, Okgye-myeon, San-gye-ri, $37^{\circ} 35^{\prime} 44^{\prime \prime} \mathrm{N}, 128^{\circ} 55^{\prime} 19^{\prime \prime} \mathrm{E}$, elev. ca. 240 m, 4 May 2015, NIBRMS107479 (KB).

Distribution: China, Japan, India, Africa, Europe, North America, and Korea.

Chenia is distinguished from related genera by the features, which are the dentate upper leaf margins, large and epapillose upper leaf laminal cells, and thin costa (Zander, 1989). This species is small and slender, and has a characteristic, which is in leaf cross-section with stereids absent.

27. Eucladium verticillatum (With.) Bruch \& Schimp.

Specimen examined: SOUTH KOREA. Gangwon-do: Samcheok-si, Dogye-eup, Mugeon-ri, $37^{\circ} 15^{\prime} 28.5^{\prime \prime} \mathrm{N}$, $129^{\circ} 6^{\prime} 39.3^{\prime \prime} \mathrm{E}$, elev. 474 m, 31 May 2017, NIBRMS107455 (KB).

Distribution: China, Japan, India, northern Africa, Russia, Europe, North America, and Korea.

Eucladium is a monotypic genus (Li et al., 2001). This species is known to be distributed on limestone areas. In the case of Japan, this plant usually grows on cliffs near the sea in Japan (Noguchi, 1988).

28. Geheebia constricta (Mitt.) R. H. Zander \& Caners Specimen examined: SOUTH KOREA. Gangwon-do: Gangneung-si, Okgye-myeon, San-gye-ri, 37³5'50'N, 128 55'18"E, elev. 250 m, 4 May 2025, NIBRMS107360 (KB).

Distribution: China, Japan, India, Indonesia, Myanmar, Nepal, Pakistan, the Philippines, and Korea.

This species is distinguished by its percurrent costae, leaf margin revolute at middle, and median cells rounded-qudrate or -triangular.

\section{Syntrichia sinensis (Müll.Hal.) Ochyra}

Specimen examined: SOUTH KOREA. Gangwon-do: Samcheok-si, Dogye-eup, Mugeon-ri, $37^{\circ} 15^{\prime} 25.5^{\prime \prime} \mathrm{N}$, 1296'39.3"E, elev. 474 m, 31 May 2017, NIBRMS107374-a (KB).

Distribution: China, central and northern Asia, Europe, North America, northern Africa, and Korea.

This species is usually known to grow on limestone soils (Mishler, 2007). We discovered this species in Samcheok-si, a typical limestone region in Korea.

30. Tortella japonica (Besch.) Broth.

Specimen examined: SOUTH KOREA. Gangwon-do: Samcheok-si, Dogye-eup, Mugeon-ri, $37^{\circ} 15^{\prime} 25.06^{\prime \prime} \mathrm{N}$, $129^{\circ} 6^{\prime} 53.24^{\prime \prime E}$, elev. ca. 620 m, 5 May 2015, NIBRMS107365 (KB).

Distribution: Japan, Mexico, and Korea.

This species is distinguished from other ones of Tortella by a short stem with a central strand.

31. *Tuerckheimia svihlae (E. B. Bartram) R. H. Zander. Specimen examined: SOUTH KOREA. Gangwon-do: 
Gangneung-si, Okgye-myeon, San-gye-ri, $37^{\circ} 34^{\prime} 23^{\prime \prime} \mathrm{N}$, 128 54'57"E, elev. 300 m, 4 May 2015, NIBRMS107362 (KB).

Distribution: China, Japan, India, Myanmar, and Korea

Park and Choi (2007) firstly reported this species to Korea, but they did not show evidence of distribution of this species. Li et al. (2001) reported a specimen collected in Baekdusan Mt. (Changbai Mountain). This study is firstly verified the habitat of this species in Korea.

\section{Weissia exserta (Broth.) P. C. Chen}

Specimen examined: SOUTH KOREA. Incheon: Ongjin-gun,

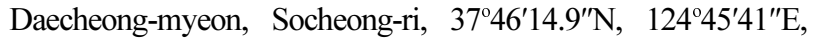
elev. $72 \mathrm{~m}$, NIBRMS107373 (KB).

Distribution: China, Japan, India, and Korea.

This species differs from ones of Weissia by capsules cleistocarpous and exserted.

\section{Pterigynandraceae}

33. Heterocladium capillaceum Broth. Ex Ihsiba

Specimen examined: SOUTH KOREA. Jeju-do: Seogwiposi, Namwon-eup, Harye-ri, near the 2nd Harye Bridge, on rock in dry valley, $33^{\circ} 17^{\prime} 8.1^{\prime \prime} \mathrm{N}, 126^{\circ} 36^{\prime} 32.2^{\prime \prime} \mathrm{E}$, elev. $120 \mathrm{~m}, 31$ Oct 2015, NIBRMS107384 (KB).

Distribution: Japan and Korea.

Heterocladium is minute, slender, and stems creeping. This species has broadly lanceolate branch leaves with indistinct costa and irregular hexagonal or rectangular median cells.

\section{Ptychomitriaceae}

34. Campylostelium brachycarpum (Nog.) Z. Iwats., Yuk. Tateishi \& Tad.Suzuki

Specimen examined: SOUTH KOREA. Jeju-do: Jeju-si, Jocheon-eup, Seonheul-ri, Geomunorum, 3327'33.6"N, 126 43'33"E, elev. 360 m, 30 Jun 2016, NIBRMS107483 (KB).

Distribution: China, Japan, and Korea.

This species is distinguished from $C$. saxicola by uncleft peristomes (Noguchi, 1950).

35. Campylostelium saxicola (F. Weber \& D. Mohr) Bruch \& Schimp.

Specimen examined: SOUTH KOREA. Jeju-do: Jeju-si, Jocheon-eup, Seonheul-ri, Geomunorum, 33⒉'33.6"N, $126^{\circ} 43^{\prime} 25.2^{\prime \prime} \mathrm{E}$, elev. ca. 360 m, 2 Nov 2015, NIBRMS107468 (KB).

Distribution: Eurpoe, North America, China, Tawian, Japan and Korea.

This species is usually distributed on moist and shaded volcanic boulders (Li et al., 2001). The habitat of Korean plants is similar to that of China.

\section{Pylaisiaceae}

36. *Ectropothecium zollingeri (Müll. Hal.) A. Jaeger.

Specimen examined: SOUTH KOREA. Jeju-do: Jeju-si,

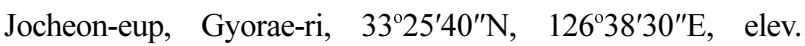
490 m, 31 Oct 2015, NIBRMS107465 (KB).

Distribution: China, India, Japan, Nepal, Southeast Asia, Pacific Islands, Hawaii, and Korea.

This species was firstly recorded by Park and Choi (2007), but references are not presented. In this study, it is firstly verified to be distributed in Jeju Island. Ectropothecium differs from related taxa having a large and bulging basal corner cell.

37. *Pylaisia stereodontoides Broth. \& Yasuda ex Ihsiba Specimens examined: SOUTH KOREA. Jeju-do: Jeju-si, Sallokbuk-ro, Gwaneumsa Temple Trail, foot of the northern

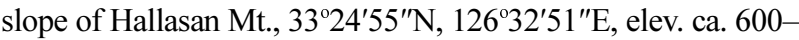
1,000 m, 28 May 2016, NIBRMS107473 (KB). Gangwon-do: Pyeongchang-gun, Jinbu-myeon, Makdong-ri, 37³3'15.4"N, $128^{\circ} 32^{\prime} 44^{\prime \prime}$, elev. ca. 620 m, 30 May 2016, NIBRMS107474 (KB).

Distribution: Korea and Japan.

Although Toyama (1938) reported a new species, Pylaisa cardotii, based on a specimen collected on Mt. Deogyu (Tokuyû-san), this species has not been listed at the moss checklist of Korea. Arikawa (2004) treated this species as a synonym of $P$. stereodontoides by re-examing its type specimen deposited at the herbarium of Kyoto University (KYO). This study verified that this species is growing in Hallasan Mt. and Gangwon-do.

38. *Vesicularia ferriei (Cardot \& Thér.) Broth.

Specimen examined: SOUTH KOREA. Jeju-do: Jeju-si, Aewol-eup, Napeup-ri, Geumsan Park, 3326 $3.7^{\prime \prime} \mathrm{N}, 126^{\circ} 19^{\prime} 48.5^{\prime \prime} \mathrm{E}$, elev. 130 m, 1 Jul 2017, NIBRMS107367 (KB).

Distribution: China, Japan, and Korea.

This species was firstly recorded by Park and Choi (2007), but references are not presented. In this study, it is verified for this species to grow in Jeju Island. Deuguchi et al. (1998) and He and Song (2007) reported V. flaccida and V. montagnei from Ulleung Island. Sometimes, Vesicularia is confused with Ectropothecium. However, Vesicularia has alar cells not or slightly differentiatted and pelucid, and leaf margin entire or slightly serrulate at the apex.

\section{Seligeriaceae}

39. Seligeria calcarea (Hedw.) Bruch \& Schimp. 
Specimen examined: SOUTH KOREA. Gangwon-do: Samcheok-si, Dogye-eup, Mugeon-ri, $37^{\circ} 15^{\prime} 28.5^{\prime \prime} \mathrm{N}$, 1296'39.3"E, elev. 474 m, 31 May 2017, NIBRMS107370 (KB).

Distribution: Europe, North America, and Korea.

The genus Seligeria is a typical genus distributed in limestone areas, and was firstly known to Korea by Tanaka et al. (2001). This species is distinguished by a costa extending to the leaf apex and excurrented.

40. Seligeria diversifolia Lindb.

Specimen examined: SOUTH KOREA. Gangwon-do: Samcheok-si, Dogye-eup, Mugeon-ri, $37^{\circ} 15^{\prime} 28.5^{\prime \prime} \mathrm{N}$, $129^{\circ} 6^{\prime} 39.3^{\prime \prime}$, elev. 474 m, 31 May 2017, NIBRMS107371 (KB).

Distribution: China, Ukraine, Europe, Greenland, North America, and Korea.

This species has charancterics, which are a costa not excurrent, seta straight or slightly curved when wet.

\section{Seligeria donniana (Sm.) Müll. Hal.}

Specimen examined: SOUTH KOREA. Gangwon-do:

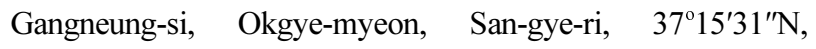
129 4'44"E, elev. 200 m, 5 May 2015, NIBRMS107363 (KB).

Distribution: Europe, North America, China, Japan, and Korea.

This specis simply differs from ones of Seligeria by peristomes absent.

\section{Taxiphyllaceae}

42. *Taxiphyllum cuspidifolium (Cardot) Z. Iwats.

Specimens examined: SOUTH KOREA. Jeju-do: Seogwipo-si, 36 Chilsimni-ro, Sojeongbang Waterfall, evergreen broad-leaved forest, $33^{\circ} 14^{\prime} 44.6^{\prime \prime} \mathrm{N}, 126^{\circ} 34^{\prime} 38.0^{\prime \prime} \mathrm{E}$, elev. ca. 38 m, 29 Jun 2016, NIBRMS106351; Jeju-si, Aewoleup, Nabeup-ri, Geumsan Park, 3326 $03.7^{\prime \prime} \mathrm{N}, 126^{\circ} 19^{\prime} 48.5^{\prime \prime} \mathrm{E}$, elev. ca. 130 m, 1 Jul 2016, NIBRMS 0000106353, NIBRMS 0000106354 (KB); Jeju-si, Aewol-eup, Nabeup-ri, Geumsan

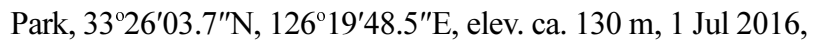
NIBRMS 106355, NIBRMS106356, NIBRMS106168 (KB).

Distribution: China, Japan, North America, and Korea.

This species was first reported by Park and Choi (2007). However, there was no any reference and distribution information. This study verifies that this species is distributed in Gangwon-do, Korea. This species is known as a calciphilous plant (Noguchi, 1994).

43. Taxiphyllum deplanatum (Bruch \& Schimp. ex Sull.) M. Fleisch.
Specimens examined: SOUTH KOREA. Gangwon-do: Gangneung-si, Okgye-myeon, San-gye-ri, 37 35'50.3'N, 128 55'9.2"E, elev. ca. 340 m, 4 May 2016, NIBRMS107466$b$ (KB); Samcheok-si, Dogye-eup, Mugeon-ri, 37 $15^{\prime} 25^{\prime \prime} \mathrm{N}$, $129^{\circ} 6^{\prime} 53.2^{\prime \prime}$, elev. 620 m, 5 May 2015, NIBRMS107467 (KB).

Distribution: North America and Korea.

This species is distinguished by leaf feature with abruptly acute or filiform at the leaf apex.

ORCID: Wonhee KIM (https://orcid.org/0000-0002-78424001); Tomio YAMAGUCHI (https://orcid.org/0000-00020640-4298)

\section{Acknowledgments}

This work was supported by a grant from the National Institute of Biological Resources (NIBR), funded by the Ministry of Environment (MOE) of the Republic of Korea (NIBR202002121).

\section{Conflict of Interest}

The authors declare that there are no conflicts of interest.

\section{Literature Cited}

Arikawa, T. 2004. A taxonomic study of the genus Pylaisia (Hypnaceae, Musci). Journal of the Hattori Botanical Laboratory 95: 71-154.

Deguchi, H., M. Higuchi \& D. M. Choe. 1998. Mosses of Ulrung Island, Korea. Hikobia 12: 365-367.

Frey, W., J.-P. Frahm, E. Fischer and W. Lobin. 2006. The Liverworts, Mosses and Ferns of Europe. Harley Books, Colchester, $512 \mathrm{pp}$.

Goffinet, B., W. R. Buck and A. J. Shaw. 2009. Morphology, anatomy, and classification of the Bryophyta. In Bryophyte Biology. 2nd ed. Goffinet, B. and A. J. Shaw (eds.), Cambridge University Press, Cambridge. Pp. 55-138.

He, S. and S. J. Song. 2007. New records of mosses from Ulleung Island, Korea. Journal of Phytogeography and Taxonomy 55: 99-102.

Higuchi, M. 2011. Endemic species of bryophytes in Japan. Bulletin of the National Museum of Nature and Science, Series B (Botany) 37: 117-126.

Hu, R.-L., Y.-F. Wang, M. R. Crosby and S. He. 2008. Moss Flora of China. Vol. 7. Amblystegiaceae-Plagiotheciaceae. Science Press, Beijing and Missouri Botanical Garden, St. Louis, MO, $258 \mathrm{pp}$. 
Ignatov, M. S., O. M. Afonina, O. I. Kuznetsova and E. A. Ignatova. 2012. The genus Leptopterigynandrum (Taxiphyllaceae, Bryophyta) in Russia. Arctoa 21: 207-220.

Jamieson, D. W. 1976. A Monograph of the Genus Hygrohypnum Lindb. (Musci) (Unpublished doctoral dissertation thesis). University of British Columbia. Vancouver.

Li, X.-J., M. R. Corsby and S. He. 2001. Moss Flora of China. Vol. 2. Fissidentaceae-Ptychomitriaceae. Science Press, Beijing and Missouri Botanical Garden, St. Louis, MO, 283 pp.

Mishler, B. D. 2007. Pottiaceae, 33. Syntrichia. In Flora of North America. Vol. 27. Bryophytes. Part 1. Mosses. Flora of North America Editional Committee (ed.), Oxford University Press, New York. Pp. 618-627.

Noguchi, A. 1950. Notes on Japanese Musci (10). Journal of Japanese Botany 23: 78-84.

Noguchi, A. 1988. Illustrated Moss Flora of Japan. Part 1. Hattori Botanical Laboratory, Nichinan. Pp. 243-491.

Noguchi, A. 1989. Illustrated Moss Flora of Japan. Part 3. Hattori Botanical Laboratory, Nichinan. Pp. 493-742.

Noguchi, A. 1991. Illustrated Moss Flora of Japan. Part 4. Hattori Botanical Laboratory, Nichinan. Pp. 743-1012.
Noguchi, A. 1994. Illustrated Moss Flora of Japan. Part 5. Hattori Botanical Laboratory, Nichinan. Pp. 1013-1253.

Park, K.-W. and K. Choi. 2007. New List of Bryophytes in Korea 2007. Korea National Arboretum, Pocheon, 150 pp.

Seppelt, R. D., R. R. Ireland Jr. and H. Robinson. 2007. Ditirichaceae, 3. Ditrichum. In Flora of North America, Vol. 27. Bryophytes. Part 1. Mosses. Flora of North America Editional Committee (ed.), Oxford University Press, New York. Pp. 450-458.

Tanaka, A., H.-T. Im and H. Ikeda. 2001. Four mosses new to the Korean Peninsula found in a calcareous area of Kangwon-do, South Korea. Bryological Research 8: 23-24.

Toyama, R. 1938. Pylaisiae Japonicae. Acta Phytotaxanomica et Geobotanica 7: 222-235.

Wu, P.-C., M. R. Crosby and S. He. 2002. Moss Flora of China. Vol. 6. Hookeriaceae-Thuidiaceae. Science Press, Beijing and Missouri Botanical Garden, St. Louis, MO.

Zander, R. H. 1989. Seven new genera in Pottiaceae (Musci) and a lectotype for Syntrichia. Phytologia 65(6): 424-436.

Zander, R. H. and P. M. Eckel. 2017. Notes on Pleuroweisieae (Pottiaceae, Bryophyta) in North America. Evansia 34: 61-64. 